\title{
A EXPANSÃO DO REINO DO DAOMÉ E A EMERGÊNCIA DA NAÇÃO FON NO INTERIOR DA AMÉRICA PORTUGUESA (MARIANA, 1715-1760)
}

\section{Vinícius Lima Lustoza*, Aldair Carlos Rodrigues.}

\section{Resumo}

O tema deste projeto de pesquisa é a diáspora dos Fons do Golfo do Benim para a região das Minas na primeira metade do século XVIII. O objetivo é estudar as dinâmicas subjacentes à emergência da nação Fon em Mariana setecentista e seus significados, privilegiando os efeitos da formação e expansão conflituosa do Reino do Daomé, a escravização do grupo naquele contexto e seu envio para a zona aurífera por meio do tráfico transatlântico. Portanto, a abordagem analítica do projeto leva em conta as dinâmicas internas do continente africano, a dimensão atlântica e as suas experiências nas minas do século XVIII

\section{Palavras-chave:}

diáspora africana, fon, reino do Daomé

\section{Introdução}

A historiografia tradicional do Reino do Daomé considera o etnônimo fon com um significado específico, o de daomeano. Contudo esta historiografia que tem como base uma leitura de registros feitos principalmente por etnógrafos franceses no Reino do Daomé em meados do século XIX, não levou em consideração a emergência deste termo em outros contextos. Este trabalho buscou a compreensão da emergência do etnônimo fon num contexto diferente daquele que registrou o fon como um povo específico do Daomé, o contexto da região de Mariana no século XVIII. Isto foi feito por meio da leitura de testamentos de pessoas livres que tinham escravos de nação fon. Ou seja, o trabalho teve como objetivo historicizar o termo fon por meio da leitura de fontes produzidas no interior da América portuguesa numa tentativa de compreender qual ou quais são os significados e como eles estão relacionados com o contexto da África Ocidental, região de onde estes escravos que apresentam este etnônimo são originários.

\section{Resultados e Discussão}

Praticamente todos os resultados desta pesquisa são hipóteses a respeito de novas leituras sobre o termo fon.

> Foi notado que o etnônimo apresenta uma certa regularidade na forma como está registrado até um determinado período ("fon mina") e após esta fase ele ressurge nos registros de forma diferente ("mina fon"). A inflexão disto provavelmente deve se a mudanças na dinâmica atlântica resultantes da expansão do Reino do Daomé.

> A especificidade do termo fon foi compreendida pelo modo como outros grupos (couranos/hulanos) relacionavam se com os fon.

> Foram lidos testamentos de três pessoas livres (Bárbara Luz, Jerônimo da Fonseca Barbosa e Ignácio Fagundes) à luz de uma bibliografia de diáspora e foram inseridos num contexto demográfico histórico mais amplo por meio da bibliografia.

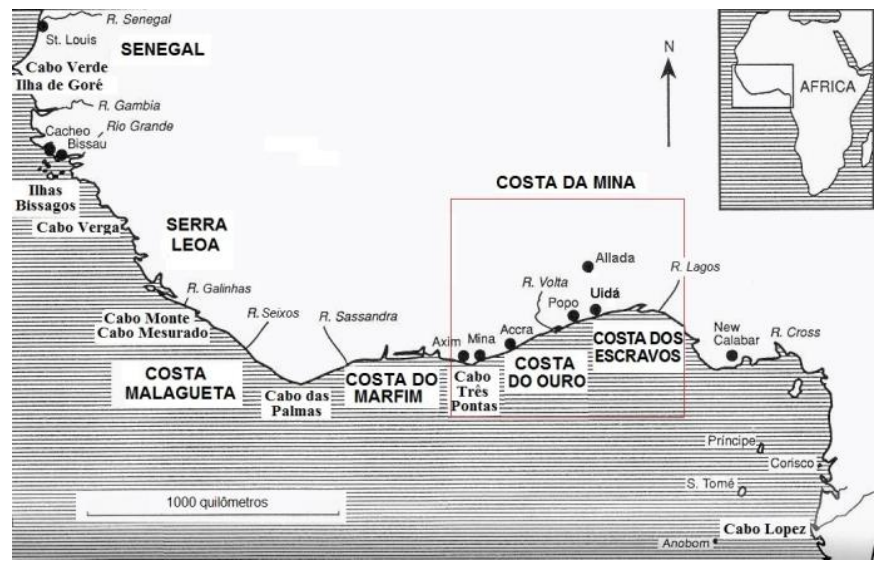

Figura 1. Costa da Guiné no século XVII [fonte: adaptado de Barbot on Guinea]

Fonte: www.costadamina.ufba.br

\section{Conclusões}

$>\mathrm{O}$ termo fon não pode ser entendido de forma monolítica, como se não houvesse variações de significados de acordo com os respectivos contextos.

> Não há nada assertivo sobre os critérios que definem o grupo fon, porém, eles não podem ser reduzidos apenas a sua região de procedência.

$>$ As alianças e rivalidades entre os diferentes grupos étnicos da África Ocidental são relidas no mundo colonial da América portuguesa, ou seja, essas relações são estendidas, porém sob uma lógica diferente.

\section{Agradecimentos}

Agradeço a ajuda e o apoio de amigos e familiares na reconstituição de algumas trajetórias que podem futuramente contribuir para o ensino de história.

\footnotetext{
${ }^{1}$ LAW, R. The Slave Coast of West Africa, 1550-1750: The Impact of the Atlantic Slave Trade on an African society. Oxford: Claredon Press, 2002 [1991].

${ }^{2}$ MAIA, M. R. D. C. De reino traficante a povo traficado: a diáspora dos courás do Golfo do Benim para as minas de ouro da América Portuguesa (1715-1760). UFRJ, 2013. (Tese de doutorado).
} 